\title{
Could basidiomycetes fungi be an alternative for the treatment of fibrous feedstuffs? Application of enzymatic complexes and future prospects
}

\author{
Miguel António Machado Rodrigues ${ }^{1}$, Rui Manuel Furtado Bezerra ${ }^{2}$, José Albino Gomes Alves \\ Dias $^{2}$, Cristina Vitória de Miranda Guedes ${ }^{1}$, Luis Miguel Mendes Ferreira ${ }^{1}$, Fernando Nunes ${ }^{3}$ \\ ${ }^{1}$ CECAV-UTAD, Department of Animal Science. \\ ${ }^{2}$ CITAB-UTAD, Department of Biology \& Environment. \\ ${ }^{3}$ CQ-UTAD, Department of Chemistry.
}

ABSTRACT - This presentation intends to make a brief description of the studies being investigated by our research group in the area valorization of fibrous feed utilizing the white-rot fungi (basidiomycetes fungi) enzyme complexes.

Key Words: basidiomycetes fungi, biological treatment, fibrous feedstuff, nutritional value, white-rot fungi

\section{Fungos basidiomicetos podem ser uma alternativa para o tratamento de alimentos fibrosos? Aplicação de complexos enzimáticos e perspectivas futuras}

RESUMO - Esta apresentação pretende fazer uma breve descrição dos estudos que têm sido investigados pelo nosso grupo de pesquisa na área de valorização de alimentos fibrosos, utilizando o fungo de podridão branca (fungos basidiomicetos) complexos enzimáticos.

Palavras-chave: alimento fibroso, fungos basidiomicetos, fungos de podridão-branca, tratamento biológico, valor nutricional

\section{Introduction}

The use of fibrous feedstuffs in animal feed has been recurrent and it is an integrating part of the mankind's evolution and of the different mechanisms of the animal domestication. Nevertheless, there are nutritional restrictions that are the result of low nitrogen content, high cell wall constituents, presence of toxic and/or antinutritional compounds, low levels of dry matter intake and of low palatability.

However, in several regions of the globe, such feedstuffs are the only ones available due to a set of different reasons. Tropical and subtropical regions are a typical example of production systems where, due to weather conditions, social, economic and technological reasons, the so-called "mixed crop livestock systems" prevail. It should also be mentioned that, nevertheless, also in Europe, namely along the Mediterranean bay countries, the supply of fibrous feeds to animals is traditional, particularly cereal straw and natural grassland hay.

Considerable effort has been made in order to try to improve the nutritive value of the cereal straw. Several treatments have been tested, and most of the published data refers to the utilizations alkaline solutions, such as sodium or ammonia hydroxide and urea, useful in the degradation of the ester bonds at the level of the vegetable cell wall, and therefore improving its digestion (Wang et al., 2004). The treatment with urea has been used to improve the content of crude protein (CP) and the fiber digestibility (Dias-da-Silva \& Sundstøl, 1986; Dias-da-Silva et al., 1988, Dias-da-Silva \& Guedes, 1990).

According to recent data (Shiere et al., 2004), the use of straws and scraps has been gaining importance, as animal feed, as for the building of structures, improvement of soil, mushroom production and other industrial uses. Besides the increasing demand for traditional uses (paper production, biomass fuel, composting, animal feed, etc), the emerging markets for the use of lignocellulosic products has been growing at a steep rate (Malherbe \& Cloete, 2002). Cell wall constituents

The cell walls are essentially composed of polysaccharides which molecular compounds are associated to, originating a tridimensional complex structure. The cell walls are laid out in a cellulosic fibrillar phase inserted in a matrix composed by non-cellulosic polysaccharides, a few proteins and, in the majority of the secondary walls, lignin 
(Lam et al., 1990). Other compounds in the cell wall include suberin, cutine, tannins, waxes, minerals and phenolic acids (Lam et al., 1990).

The monomeric constituents of the most important polysaccharides, include pentosis (arabinosis and xylose), hexoxes (glucose, galactose and mannose), 6-deoxi-hexoses (ramnose and fucose), a branched monosaccharide (apiose) and aceric, glucuronic and galacturonic acids (Coll et al., 1992).

The cellulose occurs in the vegetable kingdom as a cell wall compound and, in many plants it is their main constituent. This polymer represents around 20 to $30 \%$ of dry matter in the primary walls and $5 \%$ of the cell wall volume (Varner \& Lin, 1989). Structurally, the cellulose is defined as a D-glucose linear polymer in the shape of a pyranose ring, in which every glucose monomer presentedd in the chain suffers a rotation of approximately $180^{\circ}$ in relation to the polymer axis and to the immediately adjacent monomers. As result, cellobiose may be considered a repetitive unit structure of cellulose chains. The hemicelluloses are the second most abundant glucidic fraction in the vegetable cell walls, constituting around $10-25 \%$ of the dry matter of the forages and agro-industrial products, and around 2$12 \%$ of the seed and root dry matter (Giger-Reverdin, 1995). Briefly, hemicelluloses encompass polysaccharides that do not identify with cellulose and pectic substances, representing a fraction of polysaccharides of low molecular weight soluble in alkaline and acid solutions (Van Soest, 1994). According to that criterion, hemicelluloses are composed by a set of highly heterogeneous compounds, classified arbitrarily according to its chemical constitution, including xylans, mannans, glucomannans, galactans and arabans at variable proportions. The L-ramnose, L-fucose L-ramnose, L-fucose, the D-glucuronic and D-galacturonic acids and several methylated neutral sugars are also frequently described as constituents of hemicelluloses (Timel, 1964). The main non-glycidic fraction of the cell wall is represented by lignin. It is a complex tridimensional molecule constituted by amorphous phenylpropanoid units (C6-C3) of high molecular weight that integrates to the polymeric phenolic compounds (Susmel \& Stefanon, 1993). The nature of such units is responsible for the lignin hydrophobicity and the existing network linkage between the units is responsible for the cell wall rigidity (Theander \& Westerlund, 1993). The four cinnamic acids that universally occur in plants are the $p$-coumaric acid, the capheic acid, the ferulic acid and the synapic acid (Hartley, 1990). The $p$-coumaric and ferulic acids may also be present in the cell walls as dimers (Hartley, 1990). From the structural stand point of cell wall such compounds are characterized by presenting bonds with several constituents, namely celluloses, hemicelluloses and lignin, among others.

\section{Cell wall structure}

Plants grow through a process of cell division, followed by cell expansion. During the primary growing phase the cell wall is constituted by polysaccharides (cellulose and xylans), proteins, pectins and phenolic acids (ferulic and $p$-coumaric). Subsequently, the differentiation process takes place, which originates the different types of cells and tissues present in the plant organs. When the second stage begins, the cell walls undergo a thickening process from the primary wall to the cell center. The polysaccharidic material deposited is essentially composed by celluloses, decreasing the deposition of xylans. The incorporation of pectins and ferulic acid are interrupted at this point. Once the interactions between the several cell wall constituents are responsible for its tridimensional structure, characterized by a high grade complexity, it is important to understand how the different molecules are interconnected to one another.

The cellulose is linked to hemicelluloses by hydrogen bounds, and there is no evidence of any other covalent bonds between the cellulose and other cell wall compounds (Giger-Reverdin, 1995). The hemicellulose molecules have a high capacity for interaction with other cell wall compounds besides the cellulose, namely direct and indirect ester and/or ether bonds between some hemicelluloses or uronic acids of the hemicelluloses, pectins and lignins (Lam et al., 1992; Theander \&Westerlund, 1993). The compounds in the cell wall that allow such link to be established are hydroxicinnamic acids, namely the ferulic acid and p-coumaric acid (Harris \& Hartley, 1990). These phenolic compounds exist as monomers linked to other cell wall constituents and also as esterified and etherified dimers (Harris \& Hartley, 1990).

In the primary walls, the ratios of xyloglucans, pectic polyssacharides and protein are quite reduced. The xyloglucans polymers are short and closely associated to cellulose microfibrils. The araboxylans constitute the main polymer responsible for the establishment of cross-bonds between adjacent cellulose molecules (Chesson \& Forsberg, 1997). The monomer skeleton is extensively replaced by arabinose units which, are further replaced by ferulic acid units or, less often, by $p$-coumaric acid (Chesson \& Forsberg, 1997). The cellulose fibrils from the secondary cell walls are perfectly oriented in a parallel arrangement (Terashima et al., 1993). The xylans are deposited along with the cellulose and are likely to perform similar function, which is to establish cross-bonds between adjacent chains. However, 
such polymers are structurally different from araboxylans from the primary wall.

At the beginning of the lignification process a higher deposition of hydroxiphenil units seems to occur and less guaiacyl. As the process evolves and encompasses the secondary cell wall, the percentage of hydroxiphenil units decreases and there is an increase in the siringil units (He \& Terashima, 1989). The ferulic acid is much more important than the $p$-coumaric acid for the primary walls, whereas the latter prevails in the secondary walls, increasing its concentration as the plant grows (MullerHarvey et al., 1986).

\section{Cell wall structure as a limiting factor to degradation}

The three-dimensional structure of the cell wall is a barrier for the action of several enzymatic systems responsible for its degradation. As any structure that presents considerable dynamics, the cell wall developed, along its evolutionary process, a set of characteristics which would allow its survival as essential constituent of the plant. Such statement, besides demonstrating the different structural patterns that may occur at cell wall level, also indicates the existence of a complex set of factors that may influence its digestion.

The lignification phenomena of cell walls, intrinsically linked to the growth physiology of the plant, is considered by many authors as one of the main limiting factors of the digestion of fibrous feedstuffs. However, the complex nature of such polymers associated to a purely random polymerization, presupposes the existence of several mechanisms of action. The significant and inverse relation between the concentration of lignin and the digestibility of fibrous feeds is widely known, reducing the digestibility of dry matter, organic matter and, forages cell wall, namely, of NDF fraction (Van Soest, 1994). The plant maturation stage is related to the content of lignin (Aman, 1985). The cell wall maturation process and the digestibility are negatively correlated, which is largely driven by the increase in lignin content (Jung, 1989). Obviously, an increase in the deposition of lignin causes a progressive increase in cell wall thickness, which severely impacts the relationship between the structure of the cell wall and its digestion. For example, note the importance of the increase in the secondary cell wall thickness, which substantially decreases the area available for microbial action, limits, consequently, its digestion. On the other hand, the effects higher lignin deposition would have in the conjoint structure of the middle lamella-primary wall, considered by many authors as the most indigestible fraction of cell wall, led exactly to the same direction, further confirming the crucial role that this anatomic structure plays in limiting the digestion of cell wall to the interior of the cell (Wilson \& Hatfield, 1997).

Given the differences in composition and structure of forage cell walls, it would be at least questionable whether the observed differences in digestibility are solely due to an increase in lignin content (Akin et al., 1996). Effectively, there seems to be strong evidence that the chemical composition of lignin may, at times, play essential role in limiting digestibility. The lignin from the primary wall presents a more branched structure and more intense physical association with the carbon hydrate, whereas the lignin in the secondary walls have a more linear structure (Jung \& Deetz, 1993). This fact, associated with data that confirm higher degradation of secondary walls when compared to the primary, may suggest that syringil-type lignin deposition will have a lesser damaging effect in comparison to that of the guaiacyl-type lignin deposited in the middle lamella and in primary walls (Jung \& Deetz, 1993).

Physical access is an important element in the inhibition of digestion of lignified walls within grass species (Wilson, 1993). Indeed, lignin may act through the phenomena of encrustation establishing a physical barrier between the polysaccharides and the cellulolytic bacteria (Chesson, 1988) and it is possible that the lignification increases cell wall rigidity, restricting accessibility to rumen microorganisms (Jung \& Deetz, 1993). This aspect is of such importance that the bacteria may not reach the external surface of cell walls, but only as far as the internal surface through the cell lumen. Since the cellulolytic bacteria can only digest the superficial area immediately adjacent, the ratio between superficial area and cell volume (specific surface) decreases, affecting the digestion of cell wall (Wilson, 1993). Indissolubly associated to this physical barrier effect is the effect of lignin over the enzymes that degrade the cell wall (Moore \& Hatfield, 1994). Effectively, if lignin deter the adherence of rumen microorganisms through the phenomena of encrustation, then, and keeping in mind the same functional principle, they must also be responsible by inhibition of enzyme activity, hindering the enzymes from reaching the polymers that are susceptible to degradation (Jung \& Deetz, 1993). Indeed, the presence of phenolic compounds esterified to structural polysaccharides of the cell wall may, then, play an important role in the microbial degradation of fibrous feedstuff, limiting the mechanisms of enzymatic action. If, on the one hand, the action of the esterases may break down parts of such bonds, there is (Hatfield et al., 1991), on the other hand, a percentage of inaccessible ester bonds and the majority of ether bonds are not susceptible for degradation. 
Furthermore, the possibility of those phenolic acids establishing bonds between different polysaccharides and between polysaccharides and lignin may further limit microbial action.

Use of enzymatic complexes produced by basidiomycetes fungi

Because of some problems originated in the direct application of fungi in the treatment of fibrous feed, it was proposed the hypothesis of studying how the ligninolytic enzymes produced the basidiomycetes fungus act. This model states the possibility of degrading lignin and some of the elements that create a bond between this polymer and other cell wall structural compounds, freeing the cellulose and hemicellulose molecules, so that they may be used with greater efficiency as energy source for herbivores.

On the first study (Rodrigues et al., 2008) it was verified that the enzymatic complexes extracted from basidiomycetes fungi incubated with wheat straw in solid fermentation favored the increase in digestibility in vitro of the cell wall of wheat straw after 6 days of treatment (Figure 1).

Furthermore, results obtained after the incubation of wheat straw treated with enzymatic complexes also suggested an increase in fermentation in the rumen (Figure 2).

An important finding from this study was the verification that enzymatic complexes obtained from different fungi presented distinct activities. Indeed, the analysis of Figure 3 shows potential differences in enzymatic activity, which influence the higher or lower capacity of those complexes to act at the level of the cell wall structure.
Higher ligninolytic activity levels of the laccase and peroxidase, associated to a lower activity of the cellulolytic enzymes would suggest that the enzymatic complex produced by the Trametes versicolor 2 fungus should be the one that would present a higher capacity of cell wall degradation. However, the data indicates a high capacity of degradation of the cell wall by the enzymatic complex produced by the Bjerkandera adusta fungus. If we link these data to the apparent absence of alterations in cell wall constituents (Table 1), we must assume that other enzymes may be critical in the process of cell wall delignification, and that the simple determination of cell wall compounds does not indicate possible alterations in cell wall structure.

On a second study (unpublished), we attempted to verify whether the laccase enzyme would have any influence over the lignin degradation of cell wall from wheat straw by acting on its own. An essay was designed with the duration of 4 days, during which 32 incubation media were tested. They were divided according to enzyme concentration and temperature. Two temperature groups were formed, one whose incubation temperature was $25^{\circ} \mathrm{C}$ and another whose temperature was $40^{\circ} \mathrm{C}$. Four distinct groups were formed with concentrations of 1, 2, 3, and $4 \mathrm{U}$ of enzyme/g of straw.

The results shown in Table 2 do not seem to support the lignin degradation by laccase as initially hypothesized. In fact, it was not possible to find changes in the total amount of lignin in cell wall of straw samples treated with laccase. On the other hand, the digestibility of OM and NDF suggested a negative effect of laccase on digestibility. Such effect may be explained by structural changes in the lignin molecule as a result of the enzyme action, enabling an increase in the structural complexity of the cell wall. These

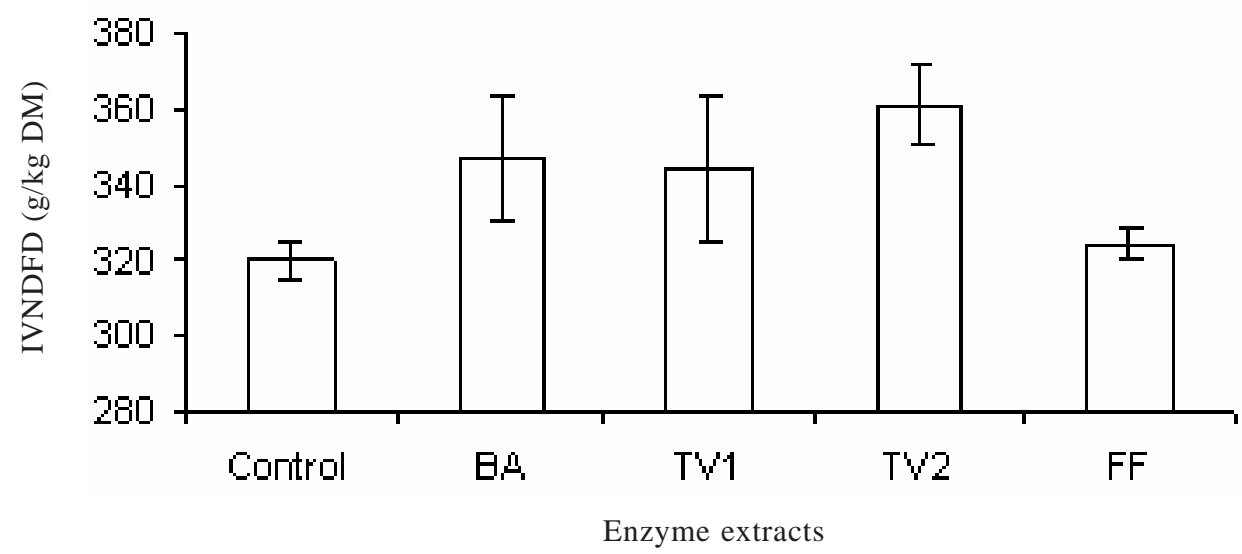

Figure 1 - Variation of in vitro NDF digestibility from wheat straw after the application of different enzymatic processes. BA - Bjerkandera adusta; TV1 - Trametes versicolor; TV2 - Trametes versicolor; FF - Fomes fomentarium. (Adapted from Rodrigues et al., 2008). 


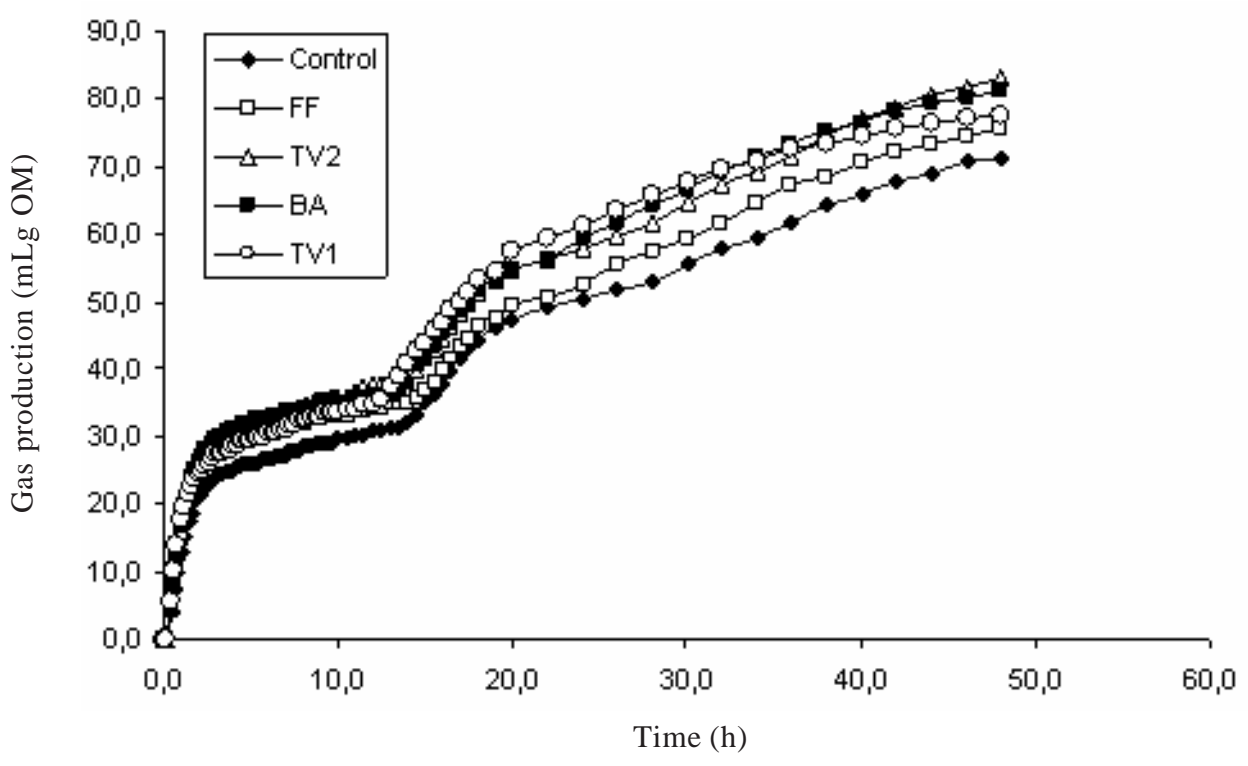

Figure 2 - Gas production in vitro of wheat straw after the application of different enzymatic complexes. BA - Bjerkandera adusta; TV1 - Trametes versicolor; TV2 - Trametes versicolor; FF - Fomes fomentarium. (Adapted from Rodrigues et al., 2008).

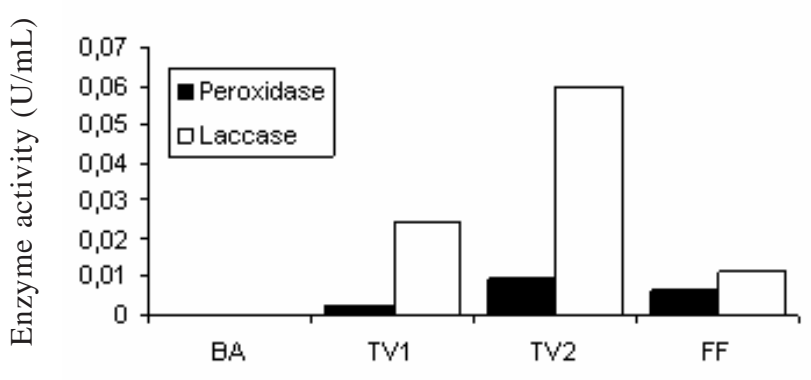

Enzyme extracts

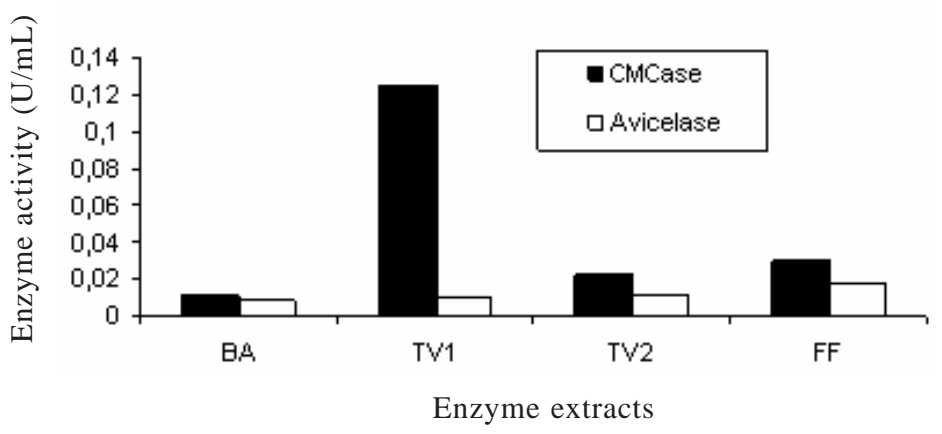

Figure 3 - Characterization of the enzymatic complex activity. BA - Bjerkandera adusta; TV1 - Trametes versicolor; TV2 - Trametes versicolor; FF - Fomes fomentarium (Adapted from Rodrigues et al., 2008). 
data, when compared to results obtained in the incubation of wheat straws with basidiomycetes fungi, seem to indicate the need for complex mechanisms of enzymatic action and with a high degree of synergy.

In that sense, the study by Dinis et al. (2009) assessed enzymatic activity of basidiomycetes fungi at different incubation times, trying to verify whether there were differences between fungi and if the production kinetics of enzymes would change along the time. The results showed that the production of the different enzymes was not the same to all fungi and that there were important variations according to the incubation time (Table 3).

When analyzing the effect of the fungi in the amount of lignin and of hydroxycinnamic acids, it was not identified

Table 1 - Chemical composition of the cell wall from wheat straw (\%DM). BA - Bjerkandera adusta; TV1 - Trametes versicolor; TV2 - Trametes versicolor; FF - Fomes fomentarium (Adapted from Rodrigues et al., 2008)

\begin{tabular}{|c|c|c|c|c|c|}
\hline Fungi & NDF & $\mathrm{ADF}$ & ADL & Cellulose & Hemicellulose \\
\hline BA & $95.6 a$ & $62.3 \mathrm{bc}$ & 10.5 & $51.8 \mathrm{~b}$ & $33.3 a$ \\
\hline TV1 & $96.4 \mathrm{~b}$ & $60.5 a$ & 10.1 & $50.4 \mathrm{a}$ & $35.9 c$ \\
\hline TV2 & $95.8 \mathrm{a}$ & $62.2 \mathrm{bc}$ & 10.5 & $51.7 \mathrm{~b}$ & $33.6 a$ \\
\hline $\mathrm{FF}$ & $96.4 b$ & $63.0 \mathrm{c}$ & 11.1 & $52.0 \mathrm{~b}$ & $33.4 \mathrm{a}$ \\
\hline Control & $96.4 \mathrm{~b}$ & $61.5 b$ & 10.4 & $51.1 \mathrm{ab}$ & $34.9 \mathrm{~b}$ \\
\hline SEM & 0.15 & 0.29 & 0.37 & 0.42 & 0.26 \\
\hline
\end{tabular}

$\mathrm{SEM}=$ standard error of the mean. Values on the same column and belonging to the same effect with different letters are significantly different (P<0.05).

Table 2 - Chemical composition of the straw (\%DM) and in vitro digestibility of OM and NDF (\%)

\begin{tabular}{|c|c|c|c|c|c|c|c|c|}
\hline Effect & DM & NDF & $\mathrm{ADF}$ & $\mathrm{LKl}$ & DOM & DNDF & HEM & CEL \\
\hline \multicolumn{9}{|l|}{ Treatment } \\
\hline w/o enzyme & 26.2 & 84.1 & 54.3 & 18.7 & $39.0 \mathrm{a}$ & $34.9 \mathrm{a}$ & 29.8 & 35.6 \\
\hline w/enzyme & 24.9 & 84.7 & 54.9 & 19.8 & $33.1 b$ & $30.6 b$ & 29.8 & 35.1 \\
\hline \multicolumn{9}{|c|}{ Temperature (T) } \\
\hline $25^{\circ} \mathrm{C}$ & 26.0 & $83.4 \mathrm{~b}$ & $53.7 \mathrm{~b}$ & $17.2 \mathrm{~b}$ & 35.3 & $31.2 b$ & 29.7 & 36.5 \\
\hline $40^{\circ} \mathrm{C}$ & 25.1 & $85.4 \mathrm{a}$ & $55.5 a$ & $21.2 \mathrm{a}$ & 36.8 & $34.3 a$ & 29.9 & 34.2 \\
\hline \multicolumn{9}{|c|}{ Concentration (C) } \\
\hline $1 \mathrm{U} / \mathrm{g}$ & 26.9 & $83.7 \mathrm{~b}$ & 55.0 & $18.3 \mathrm{bc}$ & 37.2 & 32.9 & $28.7 b$ & 36.7 a \\
\hline $2 \mathrm{U} / \mathrm{g}$ & 25.5 & $83.4 \mathrm{~b}$ & 54.2 & 19.8ab & 36.1 & 31.8 & $29.3 b$ & $34.4 \mathrm{ab}$ \\
\hline $3 \mathrm{U} / \mathrm{g}$ & 25.3 & $84.0 \mathrm{~b}$ & 54.1 & $16.6 \mathrm{c}$ & 35.1 & 32.6 & 29.9b & $37.4 \mathrm{a}$ \\
\hline $4 \mathrm{U} / \mathrm{g}$ & 24.7 & $86.4 \mathrm{a}$ & 55.0 & $22.1 \mathrm{a}$ & 35.8 & 33.7 & $31.4 \mathrm{a}$ & $33.0 \mathrm{~b}$ \\
\hline
\end{tabular}

$\mathrm{CEL}$ = cellulose; $\mathrm{DOM}=$ digestibility in vitro of $\mathrm{OM}$; DNDF = digestibility in vitro of NDF; HEM = hemicelluloses; LKl = klason lignin.

Values on the same column and belonging to the same effect with different letters are significantly different $(\mathrm{P}<0.05)$.

Table 3 - Enzymatic activity of extracts obtained from incubation with wheat straw during 28 days (Adapted from Dinis et al., 2009)

\begin{tabular}{|c|c|c|c|c|c|c|c|}
\hline & \multicolumn{7}{|c|}{ Enzymatic activity (U/mL) } \\
\hline & $\mathrm{MnP}$ & LiP & Laccasee & Avicelase & CMCase & Xylanase & Feruloyl \\
\hline \multicolumn{8}{|l|}{ Fungi } \\
\hline $\mathrm{BA}$ & $1.363 \mathrm{~b}$ & $0.259 \mathrm{~b}$ & $0.004 \mathrm{a}$ & $0.006 \mathrm{a}$ & $0.006 \mathrm{a}$ & $0.041 \mathrm{a}$ & $0.018 \mathrm{ab}$ \\
\hline GA & $0.271 \mathrm{a}$ & $0.000 \mathrm{a}$ & $0.216 c$ & $0.003 a$ & $0.067 \mathrm{c}$ & $0.132 \mathrm{~d}$ & $0.032 \mathrm{c}$ \\
\hline PR & $1.928 \mathrm{c}$ & $0.000 \mathrm{a}$ & $0.049 \mathrm{~b}$ & $0.010 \mathrm{~b}$ & $0.028 \mathrm{~b}$ & $0.063 \mathrm{~b}$ & $0.016 \mathrm{a}$ \\
\hline TV & $0.144 \mathrm{a}$ & $0.000 \mathrm{a}$ & $0.062 \mathrm{~b}$ & $0.014 \mathrm{c}$ & $0.054 \mathrm{c}$ & $0.112 \mathrm{c}$ & $0.021 \mathrm{~b}$ \\
\hline \multicolumn{8}{|l|}{ Time (days) } \\
\hline 7 & $0.307 \mathrm{a}$ & $0.000 \mathrm{a}$ & $0.157 \mathrm{~b}$ & $0.008 a$ & $0.020 \mathrm{a}$ & $0.025 a$ & $0.027 \mathrm{c}$ \\
\hline 14 & $0.831 \mathrm{~b}$ & $0.058 \mathrm{~b}$ & $0.049 a$ & $0.008 \mathrm{a}$ & $0.016 \mathrm{a}$ & $0.106 \mathrm{~b}$ & $0.022 b$ \\
\hline 21 & $1.242 \mathrm{c}$ & $0.094 \mathrm{c}$ & $0.061 \mathrm{a}$ & $0.007 \mathrm{a}$ & $0.054 \mathrm{~b}$ & $0.109 \mathrm{~b}$ & $0.022 b$ \\
\hline 28 & $1.326 \mathrm{c}$ & $0.108 \mathrm{c}$ & $0.062 \mathrm{a}$ & $0.011 \mathrm{~b}$ & $0.065 a$ & $0.107 \mathrm{~b}$ & $0.016 \mathrm{a}$ \\
\hline \multicolumn{8}{|l|}{ Effects } \\
\hline Fungi & $* * *$ & $* * *$ & $* * *$ & $* * *$ & $* * *$ & $* * *$ & $* * *$ \\
\hline Time & $* * *$ & $* * *$ & $* * *$ & $* * *$ & $* * *$ & $* * *$ & $* * *$ \\
\hline Time*Fungi & $* * *$ & $* * *$ & $* * *$ & $* * *$ & $* * *$ & $* * *$ & $* * *$ \\
\hline
\end{tabular}

BA - Bjerkandera adusta; TV1 - Trametes versicolor; TV2 - Trametes versicolor; FF - Fomes fomentarium.

Values on the same column and belonging to the same effect with different letters are significantly different $(\mathrm{P}<0,05) .{ }^{* *} \mathrm{P}<0,01 ; * * * \mathrm{P}<0,001$. 
any effect on esterified $p$-coumaric acid, while the incubation with $B$. adusta fungus decreased $(\mathrm{P}<0.05)$ the quantity of ferulic acid. In addition, there was a significant reduction in the concentration of esterified hydroxycinnamic acids along the assay $(\mathrm{P}<0.001)$.

On the 7th day of incubation, the straw treated with T. versicolor and P. rufa fungi showed lower values for esterified $p$-coumaric acid and ferulic acid, indicating that the process of degradation of those fungi would be more effective at the beginning of the incubation. These results show that a decrease of around $80 \%$ to both esterified $p$-coumaric and ferulic acids was obtained until the 28 days of incubation (Table 3). However, regarding the initial concentration of hydroxycinnamic acids in wheat straw, a decrease of 72 and $77 \%$ was observed on the 21st day of incubation for the $p$-coumaric and ferulic acids, respectively, whereas in the period between the 21 st and the 28th day of incubation the reduction was only $20 \%$ for both esterified hydroxycinnamic acids. There seems to be a first phase until the 14-21 days of growth in which there is a quick reduction in $p$-coumaric and ferulic acids, and a second phase in which the values remain relatively stable, indicating that, probably, the fungi produced all the necessary enzymes for the degradation of those compounds on the first 21 days of incubation.

The reduction in the lignin content did not differ much between the distinct fungal treatments (Table 3). However, there was a significant reduction $(\mathrm{P}<0,001)$ in the total amount of lignin from day 7 until the end of the incubation period (Table 3), reaching a value of 33\%. The loss of lignin was very low on the first 7 days of incubation (13\%).
Such data shows that enzymatic complexes seem to have an effect on cell wall structure, due to the synergy between the different types of enzymes. Actually, the higher degradation of esterified hydroxycinnamic acids in the first 7-14 days of incubation, which were directly related to the activities of xylanase and feruloyl esterase during that period, precedes a more intense degradation of the lignin structures. The study also indicated that the treatments with fungi were capable of considerably reducing the content of esterified $p$-coumaric and ferulic acids.

Following some of the results obtained with the previous work, another study was designed, this time to evaluate the accessibility of the cell wall to commercial enzymes after a pretreatment with basidiomycetes fungi (Dias et al., 2010). Once again, data related to the enzymatic activity indicate that the production of such enzymes seems to be regulated by mechanisms that aim the maximization of cell wall delignification, based in the principle of synergistic action of enzymes.

The significant increase $(\mathrm{P}<0.01)$ in the reducing sugars (saccharification of substrate) indicates the degree of accessibility of cellulose molecules and of the xylans after the fungal pretreatment to cellulases and xylanases present in the commercial complex used (Figure 4). The fermentation in solid state favored the significant increase in accessibility to cellulose due to disaggregation of lignincarbohydrates complex, and saccharification was increased four-fold and three-fold, in the case of the incubation EUC-1 and I. lacteus fungi, respectively.

The results described in Figures 2 and 4, although obtained based on different methodologies indicate the

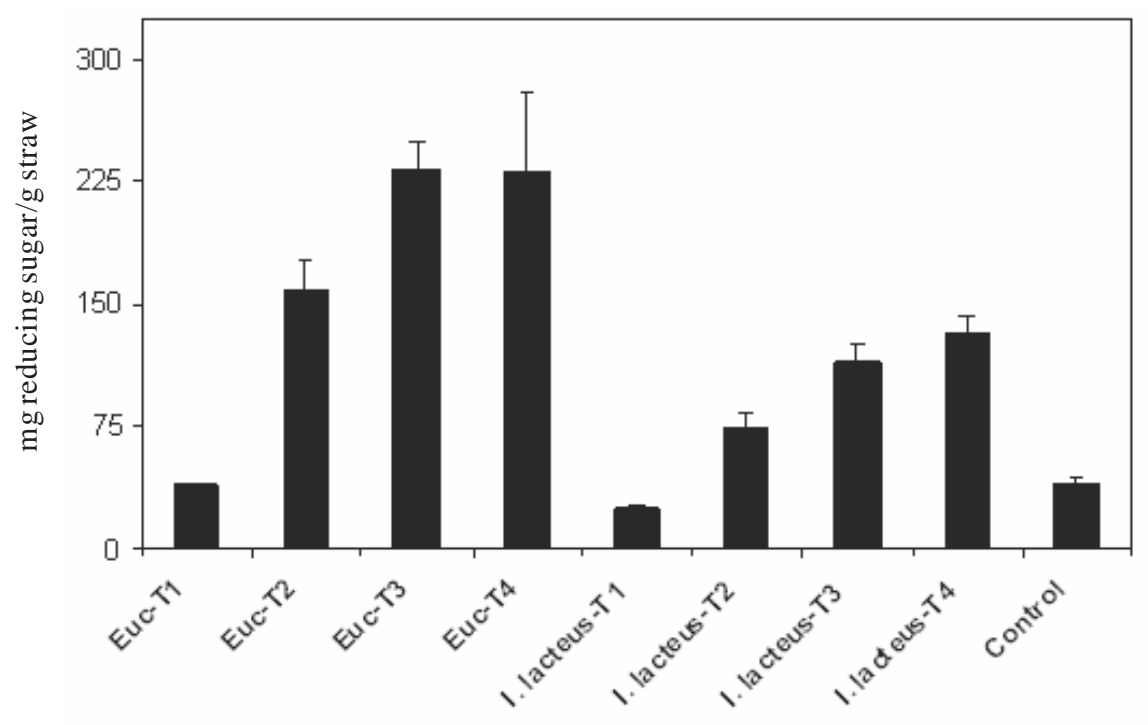

Figure 4 - Characterization of the enzymatic accessibility of wheat straw to commercial enzymes after treatment with basidiomycetes fungi along the time (Adapted from Dias et al., 2010). 
increase in the cellulose accessibility after the fungal pretreatment.

Since the previous results revealed an increase in the accessibility to the hydrolytic enzymes, a brief study was carried out in order to corelate these data with the delignification process of wheat straw and the eventual increase of cellulose-to-lignin ratio. The percentage of lignin in samples submitted to pretreatment with fungi significantly decreased $(\mathrm{P}<0.01)$ from about $20 \%$ (control) down to around 13\% after 35 days of incubation (Figure 5).

The lignin degradation reached maximum between days 35 and 46 of incubation. On the first 10 days of incubation it was not observed any reduction in lignin, which suggests once more a possible synergic role between the ligninolytic enzymes. In this synergistic action between the different enzymes the activity of feruloyl esterase should be highlighted, a fundamental enzyme in the process and yet scarcely studied in basidiomycetes fungi.

\section{Conclusions}

The results herein show an increase in the accessibility of the cellulose after the pre-treatment with white-rot fungi (B. adusta, I. lacteus, T. versicolor, P. rufa, Euc-1, I. lacteus. F. fomentarius) although presenting different potentialities. The results were obtained with pretreatments in which cultures of the above mentioned fungi were used (solid fermenting) and also with enzymatic extracts obtained from liquid cultures. After the pretreatment of wheat straw, the obtained results using several methodologies, namely, the increase in digestibility in vitro and the sugars produced after the treatment with a commercial extract of Trichoderma viride, confirm the greater accessibility of cellulose from wheat straw. The preferential degradation of the lignin demands the synergic action of several enzymes, especially manganese peroxidase, laccase and lignin peroxidase. However, in fungi where the production of laccase was not verified, such as inn $B$. adusta, also efficiently degrade lignin. In the basidiomicete fungi, the feruloyl esterase

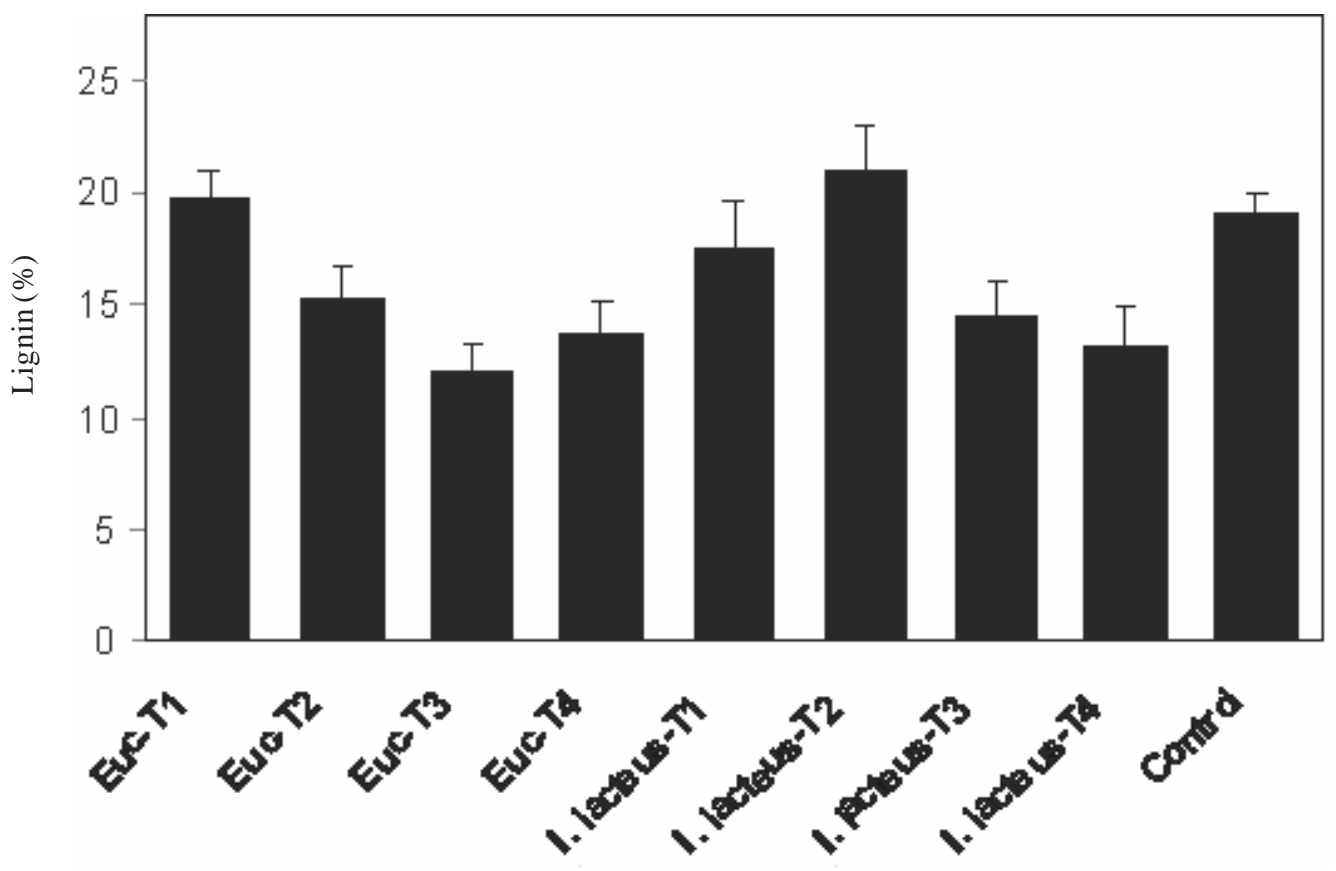

Figure 5 - Percentage of lignin that remained in the cell wall of wheat straw after treatment with basidiomycetes along the time. (Adapted from Dias et al., 2010). 
works in the breakdown of covalent bonds between lignin and hemicelluloses, probably having a synergic action with the legninolytic oxidoreductases. The initial degradation of the hydroxycinnamic acids was related to the activity of xylanase and feruloyl esterase preceding the degradation of lignin. It was also determined, during the pre-treatment, the reduction of $p$-coumaric acid and esterified ferulic acid bringing evidence of the action of esterases, namely, feruloyl esterase.

\section{References}

AKIN, D.E.; GAMBLE, G.R.; MORRINSON III, W.H. et al. Chemical and structural analysis of fibre and core tissues from flax. Journal of the Science of Food and Agriculture, v.72, p.155-165, 1996

ÅMAN, P. Chemical composition and in vitro degradability of major chemical constituents in botanical fractions of red clover harvested at different stages of maturity. Journal of the Science of Food and Agriculture, v.36, p.775-780, 1985.

CHESSON, A. Lignin-polysaccharide complexes of the plant cellwall and their effect on microbial degradation in the rumen. Animal Feed Science Technology, v.21, p.219-228, 1988.

CHESSON, A.; FORSBERG, C.W. Polysaccharide degradation by rumen microorganisms In: HOBSON, P.N.; STEWART, C.S. (Eds.) The rumen microbial ecosystem. London: Blackie Academic \& Professional, 1997. p.329-381.

COLL, J.B.; RODRIGO, G.N.; GARCÍA; B.S. et al. Fisiología vegetal. 6.ed. Madrid: Ediciones Pirámide, 1997. 662p.

DIAS, A.A. et al. Enzymatic saccharification of biologically pretreated wheat straw with white-rot fungi. Bioresource Technology (2010), doi:10.1016/j.biortech.2010.02.110.

DIAS-DA-SILVA, A.A.; GUEDES, C.V.M. Variability in the nutritive value of straw cultivars of wheat, rye and triticale and response to urea treatment. Animal Feed Science and Technology, v.28, p.79-89, 1990.

DIAS-DA-SILVA, A.A.; MASCARENHAS, A.F.; GUEDES, C.V.M. Effects of moisture level, treatment time and soya bean addition on the nutritive value of urea-treated maize stover. Animal Feed Science and Technology, v.19, p.67-77, 1988.

DIAS-DA-SILVA, A.A.; SUNDSTØL, F. Urea as a source of ammonia for improving the nutritive value of wheat straw. Animal Feed Science and Technology, v.14, p.67-79, 1986.

DINIS, M.J.; BEZERRA, R.M.F.; NUNES, F. et al. Modifications of wheat straw lignin by solid state fermentation with white-rot fungi. Bioresource Technology, v.100, p.4829-4835, 2009.

GIGER-REVERDIN, S. Review of the main methods of cell wall estimation: interest and limits for ruminants. Animal Feed Science Technology, v.55, p.295-334, 1995.

HARRIS, P.J. Plant cell wall structure and development. In: AKIN, D.E.; LJUNGDAHL, L.G.; WILSON, J.R. et al. (Eds.) Microbial and plant opportunities to improve lignocellulose utilization by ruminants. Elsevier Science Publishing Co., 1990. p.71-90.

HARRIS, P.J.; HARTLEY, R.D. Phenolic constituents of the cell wall of monocotyledons. Biochemical Systematics and Ecology, v.8, p.153-160, 1980.

HARTLEY, R.D. Phenolic monomers and dimers of the plant cell wall and their effects on fiber utilisation In: AKIN, D.E.; LJUNGDAHL, L.G.; WILSON, J.R.et al. (Eds) Microbial and plant opportunities to improve lignocellulose utilization by ruminants. Elsevier Science Publishing Co., 1990. p.183194.

HATFIELD, R.D.; HELM, R.F.; RALPH, J. Synthesisof methyl 5-O-trans-feruloyl-a-L-arabinofuranosidase and its use as a substrate to assess feruloyl esterase activity. Analytical Biochemistry, v.194, p.25-33, 1991.

HE, L.; TERASHIMA, N. Formation and structure of lignin in monocotyledons. II. Deposition and distribution of phenolic acids and their association with cell wall polymers in rice plants (oryza sativa). Mokuzai Gakkaishi, v.35, p.123-129, 1989.

JUNG, H.G. Forage lignins and their effects on fiber digestibility. Agronomy Journal, v.81, p.33-38, 1989.

JUNG, H.G.; DEETZ, D.A. Cell wall lignification and degradability. In: JUNG, H.G.; BUXTON, D.R.; HATFIELD, R.D. et al. (Eds) Forage cell wall structure and digestibility. Madison: American Society of Agronomy, Crop Science Society of America, Soil Science Society of America, 1993. p.315-346.

LAM, T.B.T.; IIYAMA, K.; STONE, B.A. Covalent polysaccharidelignin interactions through cinnamic acids in plant cell walls. In: CELl WALl MeEting, 6., 1992, Nijmegen. Proceedings... Nijmegen: 1992. p.135.

LAM, T.B.T.; IIYAMA, K.; STONE, B.A. Primary and secondary walls of grasses and other forage Plants: Taxonomic and structural considerations. In: AKIN, D.E.; LJUNGDAHL, L.G.; WILSON, J.R. et al. (Eds) Microbial and plant opportunities to improve lignocellulose utilization by ruminants. Elsevier Science Publishing Co., 1990. p.43-69.

MALHERBE, S.; CLOETE, T.E. Lignocellulose biodegradation: Fundamentals and applications. Reviews in Environmental Science \& BioTechnology, v.1, p.105-114, 2002.

MOORE, K.J.; HATFIELD, R.D. Carbohydrates and forage quality. In: FAHEY JR., G.C.; COLLINS, M.; MERTENS, D.R. et al. (Eds.) Forage quality, evaluation, and utilization. Madison: American Society of Agronomy, Crop Science Society of America, Soil Science Society of America, 1994. p.229-280.

RODRIGUES, M.A.M.; PINTO, P.; BEZERRA, R.M.F. et al. Effect of enzyme extracts isolated from white-rot fungi on chemical composition and in vitro digestibility of wheat straw. Animal Feed Science and Technology, v.141, p.326-338, 2008.

SCHIERE, J.B.; JOSHI, A.L.; SEETHARAM, A. et al. Grain and straw for whole plant value: Implications for crop management and genetic improvement strategies. Experimental Agriculture, v.40, p.277-294, 2004.

SUSMEL, P.; STEFANON, B. Aspects of lignin degradation by rumen microrganisms. Journal of Biotechnology, v.39, p.141-148, 1993.

TERASHIMA, N.; FUKUSHIMA, K.; HE, L-F. et al. Comprehensive model of the lignified cell wall. In: JUNG, H.G.; BUXTON, D.R.; HATFIELD, R.D. et al. (Eds) Forage cell wall structure and digestibility. Madison: American Society of Agronomy, Crop Science Society of America, Soil Science Society of America, 1993. p.247-270.

THEANDER, O.; WESTERLUND, E. Quantitative analysis of cell wall components. In: JUNG, H.G.; BUXTON, D.R.; HATFIELD, R.D. et al. (Eds.) Forage cell wall structure and digestibility. Madison: American Society of Agronomy, Crop Science Society of America, Soil Science Society of America, 1993. p.83-104.

TIMELL, T.E. Wood hemicelluloses. In: WOLFROM, M.L.; TIPSON, R.S. (Eds.) Advances in carbohydrate chemistry. New York: Academic Press, 1964. v.19, p.247-302

VAN SOEST, P.J. Nutritional ecology of the ruminant. 2.ed. New York: Cornell University Press, 1994.

WANG, Y.; SPRATLING, B.M.; ZOBELL, D.R. et al. Effect of alkali pretreatment of wheat straw on the efficacy of exogenous fibrolytic enzymes. Journal of Animal Science, v.82, p.198-208, 2004.

WILSON, J.R. Organization of forage plant tissues. In: JUNG, H.G.; BUXTON, D.R.; HATFIELD, R.D. et al. (Eds) Forage cell wall structure and digestibility. Madison: American Society of Agronomy, Crop Science Society of America, Soil Science Society of America, 1993. p.1-32.

WILSON, J.R.; HATFIELD, R.D. Structural and chemical changes of cell wall types during stem development: consequences for fibre degradation by rumen microflora. Australian Journal of Agricultural Research, v.48, p.165-180, 1997.

R. Bras. Zootec., v.39, p.519-527, 2010 (supl. especial) 